\title{
Pergeseran Mata Pencaharian Petani
}

\section{Shift Of Farmer Livelihoods}

\section{Idrus Hentihu1), M Chairul Basrun Umanailo1)*, Darwin Abd Radjak ${ }^{2)}$ \& Andries Lionardo ${ }^{3)}$}

\author{
1)Agroteknologi, Fakultas Pertanian dan Kehutanan, Universitas Iqra Buru, Indonesia \\ 2) Universitas Muhammadiyah Maluku Utara, Indonesia \\ 3) Universitas Sriwijaya, Palembang, Indonesia
}

Diterima: 11 Juni 2021; Disetujui: 02 Agustus 2021; Dipublish: 21 Agustus 2021

*Coresponding Email: chairulbasrun@gmail.com

\begin{abstract}
Abstrak
Tulisan ini bertujuan untuk mengkaji permasalahan berkurangnya lahan pertanian di desa Namlea yang telah menjadi lahan pembangunan infrastruktur yang baru sehingga menggeser fungsi lahan keluar dari sektor pertanian. Masalah difokuskan pada pergeseran fungsi lahan yang membuat pekerja di sektor pertanian semakin berkurang yang berpengaruh pada produktifitas. Penelitian ini berupaya untuk mengidentifikasi dampak urbanisasi serta tindakan diversifikasi yang dilakukan masyarakat terhadap lahan pertanian yang mereka miliki sebagai upaya untuk pemenuhan kebutuhan hidup sehari-hari. Penelitian ini menggunakan pendekatan kualitatif dan Jumlah informan yang akan diwawancarai sebanyak 15 orang yang diambil secara purposive. Penelitian dilakukan di Desa Namlea Kabupaten Buru dengan Informan diantaranya perangkat desa, anggota BPD, perwakilan tokoh masyarakat, tokah adat dan pemuka agama ditambah dengan perwakilan masyarakat yang diangap memiliki kompetensi terkait tujuan penelitian. Penelitian ini menggunakan teknik pengumpulan data observasi serta wawancara mendalam. Teknik analisis yang digunakan dalam penelitian ini adalah analisis data kualitatif mengikuti konsep yang diberikan Miles and Huberman dan Spradley. Kajian ini menyimpulkan bahwa dampak alih fungsi lahan menghasilkan keterbatasan petani di Desa Namlea untuk mengakses pekerjaan yang selama ini mereka dapatkan untuk memenuhi kebutuhan hidup dan harus mengerjakan pekerjaan lainnya tentu dengan bayaran yang murah, semua ini dilakukan semata-mata untuk memenuhi kebutuhan rumah tangganya.
\end{abstract}

Kata Kunci: Okupasi; Lahan Pertanian; Desa Namlea; Diversifikasi.

\begin{abstract}
This paper aims to examine the problem of decreasing agricultural land in Namlea village which has become a new infrastructure development area so that it shifts the function of land out of the agricultural sector. The problem is focused on shifting land use which makes workers in the agricultural sector less and less which affects productivity. This study seeks to identify the impact of urbanization and the diversification actions taken by the community on their agricultural land as an effort to fulfill their daily needs. This study uses a qualitative approach and the number of informants to be interviewed is 15 people who are taken purposively. The research was conducted in Namlea Village, Buru Regency with informants including village officials, BPD members, representatives of community leaders, traditional leaders and religious leaders plus community representatives who are considered to have competencies related to the research objectives. This study uses observation data collection techniques and in-depth interviews. The analytical technique used in this research is qualitative data analysis following the concept given by Miles and Huberman and Spradley. This study concludes that the impact of land conversion results in the limitations of farmers in Namlea Village to access the jobs they have been getting to meet their daily needs and have to do other jobs of course with low pay, all of this is done solely to meet household needs.
\end{abstract}

Keywords: Occupation; Farmland; Namlea Village; Diversification.

How to Cite: Hentihu, I., Umanailo, M.C.B., Radjak, D.A., \& Lionardo, A., (2021). Pergeseran Mata Pencaharian Petani. Journal of Education, Humaniora and Social Sciences (JEHSS). 4(2): 1020-1027. 


\section{PENDAHULUAN}

Pengembangan wilayah pedesaan dalam menunjang pembangunan daerah menjadi begitu penting dalam era desentralisasi, dimana hampir sebagian besar wilayah pedesaan di Indonesia masih terus dikembangkan untuk pencapaian kesejahteraan masyarakat. Seiring dengan pencapaian pembangunan masyarakat di Kabupaten Buru, maka hadirnya Namlea sebagai Ibukota Kabupaten dengan sendirinya akan melahirkan pula berbagai permasalahan sebagai konsekuensi logis dinamika masyarakat serta perubahan dari masyarakat pedesaan menjadi masyarakat perkotaan, sehingga kondisi perubahan tersebut diharapkan mampu menjadi arah dan tujuan akhir pencapaian kesejahteraan masyarakat di Kota Namlea. Dalam perkembangan masyarakat di Namlea, petani merupakan bagian penting dari struktur masyarakat yang ada, hingga pada perkembangan menjadi ibukota kabupaten.

Desa Namlea pada kajian historisnya terdapat karakteristik pertanian dan perikanan yang begitu kuat dan melekat dalam kehidupan sosial ekonomi masyarakat. Pertanian menjadi kosentrasi untuk sumber kehidupan yang diupayakan untuk mendukung kehidupan mereka sehari-hari. Kepemilikan lahan juga diperuntukan untuk usaha pertanian dan pengembangan ekonomi keluarga. Bertambahnya jumlah penduduk dan meningkatkan kebutuhan hasil pertanian, semestinya kondisi ini memiliki dampak positif terhadap pertumbuhan ekonomi petani, namun kondisi yang terjadi saat ini adalah masyarakat desa Namlea menjadi konsumen terhadap hasil pertanian dari petani di luar desa Namlea, ketersediaan hasil pertanian sangat memiliki dampak terhadap jalur, jumlah dan kondisi transportasi dari daerah penyuplai sehingga Namlea bukan lagi menjadi produsen hasil pertanian melainkan menjadi konsumen terhadap hasil pertanian dari masyarakat di luar mereka. Pengaruh kepemilikan lahan menjadi salah satu penentu terjadinya pengurangan petani dan pekerjaan di bidang pertanian. Alih fungsi menjadi konsukuensi dari permintaan pasar terhadap pengembangan wilayah untuk pembangunan pusat-pusat ekonomi dan pemerintahan.

Dengan adanya pengembangan wilayah di Namlea, keberadaan serta eksistensi petani semakin terbatas. Peralihan lahan-lahan pertanian menjadi perumahan serta perkantoran dan juga untuk perdagangan menjadikan petani semakin kesulitan, bahkan mulai terdesak untuk keluar dan mengembangkan pertanian pada lokasi yang tentunya dengan jarak yang lebih jauh dari sebelumnya. Maka urbanisasi atau dalam sosiologi dikenal dengan proses perubahan desa menjadi kota yang akan membawa dampak tersendiri bagi petani dalam pengembangan kehidupan sosial ekonominya (Deng et al., 2015). Proses pengkotaan yang terjadi tidak serta merta hanya merubah infrastruktur namun lebih dari itu terjadi juga pada masalah lahan pertanian, perubahan alih fungsi lahan dan kepemilikan, pergeseran struktur okupasi, sehingga eksistensi petani semakin terdesak akibat berkembangnya proses urbanisasi di Namlea.

Dalam konteks penelitian ini, akan dilihat bagaimana sistem pengetahuan yang dibangun oleh petani maupun masyarakat terkait dengan alih fungsi lahan pertanian dalam diametrical urbanisasi. Teori konstruksi sosial dalam penelitian ini dijadikan sebagai guidance untuk melihat realitas sosial, karena menurut Berger dan Luckmann (Berger, 1990) kontsruksi sosial dibangun melalui dua cara: Pertama, mendefinisikan tentang kenyataan atau "realitas" dan "pengetahuan". Realitas sosial adalah sesuatu yang tersirat di dalam pergaulan sosial yang diungkapkan secara sosial melalui komunikasi bahasa, kerjasama melalui bentuk-bentuk organisasi sosial dan seterusnya. Realitas sosial ditemukan dalam pengalaman intersubjektif, sedangkan pengetahuan mengenai realitas sosial adalah berkaitan dengan kehidupan bermasyarakat dengan segala aspeknya, meliputi ranah kognitif, psikomotorik, emosional dan intuitif. Kedua, untuk meneliti sesuatu yang intersubjektif tersebut, Berger menggunakan paradigma berpikir Durkheim mengenai objektivitas, dan paradigma Weber mengenai subjektivitas (. et al., 2020). Jika Durkheim memposisikan objektivitas di atas subjektivitas (masyarakat di atas individu), sementara Weber menempatkan subjektivitas di atas objektivitas (individu di atas masyarakat), maka Berger melihat keduanya sebagai entitas yang tidak terpisahkan. Masyarakat menurut Berger merupakan realitas objektif sekaligus subjektif. Sebagai realitas objektif, masyarakat berada di luar diri manusia dan berhadapan dengannya. Sedangkan sebagai realitas subjektif, individu berada di dalam masyarakat sebagai bagian yang tak terpisahkan. Dengan kata lain, bahwa individu adalah 
pembentuk masyarakat dan masyarakat juga pembentuk individu. Realitas sosial bersifat ganda (plural) dan bukan tunggal, yaitu realitas objektif dan subjektif (Latang, 2017). Realitas objektif adalah realitas yang berada di luar diri manusia, sedangkan realitas subjektif adalah realitas yang berada dalam diri manusia.

Beberapa penelitian sebelumnya seperti yang dilakukan oleh Yayat Hidayat tentang dampak konversi lahan pertanian terhadap ekonomi rumah tangga petani padi (Hidayat \& et al, 2017), I Made Yoga Prasada mengenai dampak alih fungsi lahan sawah terhadap ketahanan pangan di Daerah Istimewa Yogyakarta (Prasada \& Rosa, 2018), serta penelitian yang dilakukan oleh Bambang Hudayana mengenai The Impact of Land Commodification on Small and Landless Farmer's Access to Rent Land in the Sub-Urban Village (Hudayana, 2020). Ketiga kajian tersebut menempatkan pemilik lahan sebagai subjek yang mendapatkan tekanan untuk melakukan alih fungsi lahan yang mereka miliki, namun kondisi ini berbeda seperti yang terjadi pada desa Namlea dimana alih fungsi lahan dilihat sebagai peluang dan kesempatan dalam meningkatkan sumber perndapatan rumah tangga pemilik lahan (petani)

Kondisi seperti itulah yang menjadi persoalan dalam kajian penelitian ini sehingga peneliti beranggapan perlu adanya kajian mendalam terkait konstruksi sosial petani di dota Namlea, sehingga pada akhirnya penelitian ini mampu melahirkan temuan maupun teori yang aplikatif terhadap persoalan yang dihadapi terkait dengan pemanfaatan lahan dan pemberdayaan petani di perkotaan.

\section{METODE PENELITIAN}

Penelitian dilaksanakan di desa Namlea, Kabupaten Buru. Adapun penentuan lokasi penelitian dilakukan secara purposive (sengaja). Desa Namlea dipilih sebagai lokasi penelitian karena persentase jumlah rumah tangga petani yang semakin berkurang dengan desa lain yang berada di Kabupaten Buru. Jumlah informan yang akan diwawancara sebanyak 15 orang yang diambil secara purposive dengan pertimbangan responden dianggap sebagai pihak-pihak yang terkait untuk mencapai tujuan penelitian

Data pada penelitian ini diperoleh dari sumber data primer dan data sekunder, dengan teknik pengumpulan data yang digunakan melalui observasi, wawancara, dan studi pustaka/dokumen. Peneliti juga mencari informasi pelengkap terkait proses pengkotaan dan terjadinya diversifikasi lahan pertanian di Desa Namlea melalui internet maupun studi pustaka mengunakan dokumen/arsip pemerintah yang terkait dengan kebijakan diversifikasi lahan di Kabupaten Buru.

Teknik analisis yang digunakan dalam penelitian ini adalah analisis data kualitatif mengikuti konsep yang diberikan Miles and Huberman dan Spradley (Wijaya, 2018). Peneliti melakukan aktifitas analisis secara interaktif dan berlangsung secara terus menerus pada setiap tahapan penelitian sehingga sampai tuntas, dan datanya sampai jenuh. Aktivitas yang peneliti dilakukan dalam analisis data yaitu reduksi data (data reduction), penyajian data (data display), penarikan kesimpulan atau verifikasi (conclusion drawing/ verification).

\section{HASIL DAN PEMBAHASAN}

Secara administratif desa Namlea merupakan salah satu dari sekian banyak desa yang termasuk dalam wilayah administratif Kabupaten Buru Propinsi Maluku dengan tipe pemerintahan desa seperti desa lainnya di Kabupaten Buru, yakni dipimpin oleh seorang kepala desa yang dipilih melalui mekanisme pemilihan kepala desa yang berlangsung secara periodik. Seiring perkembangan desa Namlea saat ini sebagai pusat ibukota kabupaten maka sering terjadi perpindahan atas penguasaan lahan-lahan pertanian di desa Namlea, dengan serta merta membuat keberadaan petani juga ikut terpengaruh. Kondisi kehidupan dari yang mencukupi perlahan tergeser oleh berbagai kebutuhan dan ketersediaan sumberdaya yang ada. Situasi yang sebelumnya masih bisa dianggap membantu, saat ini malah menjadi terbalik dengan yang diharapkan. 
Transformasi pola mata pencaharian petani di desa Namlea ditandai oleh penghasilan pertanian yang sangat kecil, lahan garapan semakin sempit, biaya produksi yang besar tidak sebanding dengan nilai jual hasil pertanian, peluang usaha nonpertanian semakin terbuka dengan penghasilan yang cukup besar, generasi muda dan anak-anak petani tidak bersedia meneruskan pekerjaan pertanian orang tuanya, dan terjadi mobilitas penduduk yang dapat menghasilkan transaksi pekerjaan antara petani sebagai pihak yang membutuhkan pekerjaan dengan masyarakat pendatang sebagai pihak yang membutuhkan tenaga kerja (Hardika, 2011). Di samping itu juga muncul persepsi pada generasi muda, bahwa pekerjaan pertanian dianggap kurang prestisius, terkesan kotor, kumuh, miskin, kurang terdidik dan tidak memberikan jaminan masa depan yang jelas.

Desa Namlea pada kajian historisnya terdapat karakteristik pertanian dan perikanan yang begitu kuat dan melekat dalam kehidupan sosial ekonomi masyarakat. Dengan adanya pengembangan wilayah di Namlea, keberadaan serta eksistensi petani semakin terbatas. Peralihan lahan-lahan pertanian menjadi perumahan serta perkantoran dan juga untuk perdagangan menjadikan petani semakin kesulitan, bahkan mulai terdesak untuk keluar dan mengembangkan pertanian pada lokasi yang tentunya dengan jarak yang lebih jauh dari sebelumnya. Maka urbanisasi atau dalam sosiologi dikenal dengan proses perubahan desa menjadi kota yang akan membawa dampak tersendiri bagi petani dalam pengembangan kehidupan sosial ekonominya. Proses pengkotaan yang terjadi tidak serta merta hanya merubah infrastruktur namun lebih dari itu terjadi juga pada masalah lahan pertanian, perubahan alih fungsi lahan dan kepemilikan, pergeseran struktur okupasi, sehingga eksistensi petani semakin terdesak akibat berkembangnya proses urbanisasi di Namlea (Zhang et al., 2018). Pertanian menjadi kosentrasi untuk sumber kehidupan yang diupayakan untuk mendukung kehidupan mereka sehari-hari. kepemilikan lahan juga diperuntukan untuk usaha pertanian dan pengembangan ekonomi keluarga. Bertambahnya jumlah penduduk dan meningkatkan kebutuhan hasil pertanian, semestinya kondisi ini memiliki dampak positif terhadap pertumbuhan ekonomi petani, namun kondisi yang terjadi saat ini adalah masyarakat desa Namlea menjadi konsumen terhadap hasil pertanian dari petani di luar desa Namlea, ketersediaan hasil pertanian sangat memiliki dampak terhadap jalur, jumlah dan kondisi transportasi dari daerah penyuplai sehingga Namlea bukan lagi menjadi produsen hasil pertanian melainkan menjadi konsumen terhadap hasil pertanian dari masyarakat di luar mereka (Vandercasteelen et al., 2018).

Dalam pandangan petani di Desa Namlea, pekerjaan pertanian bukan merupakan satusatunya jenis pekerjaan yang dapat menghasilkan pendapatan. Walaupun sebelumnya pekerjaan pertanian sangat dominan di desa Namlea, namun fakta menunjukkan bahwa kehidupan sosial ekonomi masyarakat petani tidak hanya ditentukan oleh sektor pertanian (Rahma, Satya at, 2021). Seiring dengan semakin terbukanya arus informasi dan perubahan terhadap hakikat hidup di kalangan masyarakat, maka petani pun juga mengalami perubahan cara belajar dan berperilaku ekonomi dalam kehidupan sehari-hari (Et al., 2021). Pemenuhan kebutuhan hidup tidak cukup hanya dipenuhi oleh satu jenis pekerjaan saja, tetapi juga perlu ditunjang oleh pekerjaan lain dan peran sosial yang lebih produktif. Pengaruh kepemilikan lahan menjadi salah satu penentu terjadinya pengurangan petani dan pekerjaan di bidang pertanian. Alih fungsi menjadi konsukuensi dari permintaan pasar terhadap pengembangan wilayah untuk pembangunan pusatpusat ekonomi dan pemerintahan.

Kegiatan yang dilakukan di luar sektor pertanian karena tidak adanya jaminan untuk mendapatkan penghasilan yang memadai, sehingga warga yang sebelumnya berprofesi sebagai petani maupun buruh tani suka maupun tidak harus keluar untuk mengakses profesi lain, sekalipun keahlian dan kesempatan yang dimilikinya sangat terbatas (Umanailo et al., 2019). Terjadinya alih fungsi lahan dari pertanian ke sektor non pertanian dikarenakan oleh dua faktor, yaitu faktor internal yang lebih disebabkan oleh penduduk setempat atau yang kita sebut dalam penelitian ini (masyarakat tani desa Namlea) serta faktor eksternal yang lebih berbentuk kebijakan maupun investasi ekonomi. Maka secara tidak langsung akan melahirkan sebuah keterbatasan dalam mengakses sumber-sumber penghidupan petani (S. Ali et al., 2018), dalam hal ini berkaitan dengan penggunaan lahan untuk bertani, dan melahirkan kondisi secara tidak 
langsung untuk membatasi; pembatasan peran terhadap kelompok tertentu sehingga dapat mengarah pada sebuah kondisi standar kehidupan yang rendah pada sejumlah orang yang sering kita sebut kemiskinan. Kondisi seperti ini akan sendirinya memaksa masyarakat yang tidak lagi memiliki lahan pertanian sebagai sumber penghidupan bertindak sebagaimana dalam perspektif teori pilihan rasional bahwa aktor akan bertindak sesuai dengan referensi serta sumberdaya yang dimiliki serta dipengaruhi oleh norma serta kepentingan individu maupun kolektif. Dengan demikian maka masyarakat akan berpikir untuk mendapatkan sumber penghidupan yang lain seperti menjadi buruh tani, buruh bangunan, ojek, dan juga berdagang serta mengembangkan usaha-usaha lain di luar sektor pertanian agar mampu menutupi kebutuhannya, berubahnya status kepemilikan lahan serta bergesernya mata pencaharian dari pertanian ke luar sektor pertanian sehingga menjadi objek kajian tersendiri untuk konstruksi masyarakat Namlea.

Fenomena yang mengindikasikan bahwa keberadaan mereka semakin terpuruk bisa kita temukan saat pemenuhan kebutuhan sehari-hari. Meninjau alasan terkuat untuk seorang pemilik lahan menjual lahannya yaitu kebutuhan dan proses ekonomi yang terus berlangsung di desa Namlea. Dapat dikemukakan kenapa proses tersebut menjadi massif dan berlangsung secara terus menerus sampai saat ini.

Tabel 1. Dampak Alih Fungsi Lahan Terhadap Orientasi Nafkah Masyarakat Di Desa Namlea

\begin{tabular}{|c|c|c|c|}
\hline \multicolumn{4}{|c|}{$\begin{array}{ll} & \text { Orientasi Nafkah } \\
\end{array}$} \\
\hline \multicolumn{2}{|c|}{$\begin{array}{l}\text { Penguasaan Lahan Oleh Pihak Pengusaha, } \\
\text { dan Pendatang }\end{array}$} & $\begin{array}{l}\text { Kesulitan } \\
\text { Menjalankan }\end{array}$ & $\begin{array}{l}\text { Inisiatif Mencari Pekerjaan } \\
\text { di luar Sektor Pertanian }\end{array}$ \\
\hline \multirow[t]{2}{*}{ Penyebab } & $\begin{array}{lr}\text { Lahan sebagian } & \text { besar } \\
\text { diperuntukan } & \text { untuk } \\
\text { pengembangan } & \text { sarana } \\
\text { ekonomi, perkantoran } & \text { serta } \\
\text { perumahan } & \end{array}$ & Lokasi semakin sempit & $\begin{array}{l}\text { Mengandalkan pengalaman } \\
\text { bertani }\end{array}$ \\
\hline & $\begin{array}{l}\text { Kondisi lahan pertanian yang } \\
\text { lama ditinggal }\end{array}$ & $\begin{array}{l}\text { Unsur tanah semakin } \\
\text { berkurang seiring terjadinya } \\
\text { pencemaran }\end{array}$ & $\begin{array}{l}\text { Mengutamakan prinsip "asal } \\
\text { dapat pekerjaan" }\end{array}$ \\
\hline \multirow[t]{3}{*}{ Dampak } & $\begin{array}{l}\text { petani kekurangan lahan } \\
\text { maupun kesempatan kerja }\end{array}$ & $\begin{array}{l}\text { Produktivitas pertanian } \\
\text { menurun }\end{array}$ & $\begin{array}{l}\text { Mendapatkan pembagian } \\
\text { hasil pertanian maupun } \\
\text { ongkos kerja yang lebih } \\
\text { sedikit }\end{array}$ \\
\hline & $\begin{array}{l}\text { Ketidakpastian pekerjaan } \\
\text { karena sewaktu-waktu fungsi } \\
\text { lahan bisa berubah }\end{array}$ & $\begin{array}{l}\text { Biaya produksi meningkat } \\
\text { untuk memompa air dari } \\
\text { sumber air ke lahan }\end{array}$ & $\begin{array}{l}\text { Mendapatkan bayaran upah } \\
\text { maupun gaji yang murah }\end{array}$ \\
\hline & $\begin{array}{l}\text { Petani tidak bisa bekerja dan } \\
\text { terputusnya } \\
\text { penghidupan }\end{array}$ & $\begin{array}{l}\text { Hasil pertanian tidak bisa } \\
\text { dijual }\end{array}$ & \\
\hline
\end{tabular}

Sumber: Kompilasi Hasil Penelitian Lapangan Maret-April 2021

Untuk melihat perubahan dalam sistem penghidupan masyarakat meminjam pandangan dari Mazhab Bogor (Mardiyaningsih et al., 2010), karakteristik system penghidupan dan nafkah sangat ditentukan oleh sistem sosial-budaya masyarakat setempat dengan tiga elemen pentingnya, yaitu: (a) infrastruktur sosial, (b) struktur sosial, dan (c) supra struktur sosial. modernisasi pedesaan mendorong sistem penghidupan masyarakat yang sebelumnya relatif tradisional menjadi lebih modern/maju (Pannell et al., 2014). Perubahan tersebut dicirikan oleh adanya perubahan pada struktur sosial yang dapat dilihat dari perubahan pada struktur agraria yang semula bersifat komunal menjadi individual dan pola pemanfaatan sumberdaya alam yang berlandaskan kearifan local menjadi berlandaskan inovasi baru. Struktur sosial juga melihat perubahan pada strategi nafkah yang pada awalnya berbasis pada pertanian untuk memenuhi kebutuhan subsistensi akan pangan menjadi berbasis pada pertanian dan non pertanian yang 
bersifat komersial (Contzen \& Crettaz, 2019). Perubahan pada supra struktur sosial juga diperlihatkan pada etika moral ekonomi masyarakat tani yang sebelumnya lebih dominan pada moral ekonomi petani pada masyarakat yang tradisional menjadi politik ekonomi petani pada masyarakat tani yang termodernisasi (Mardiyaningsih et al., 2010).

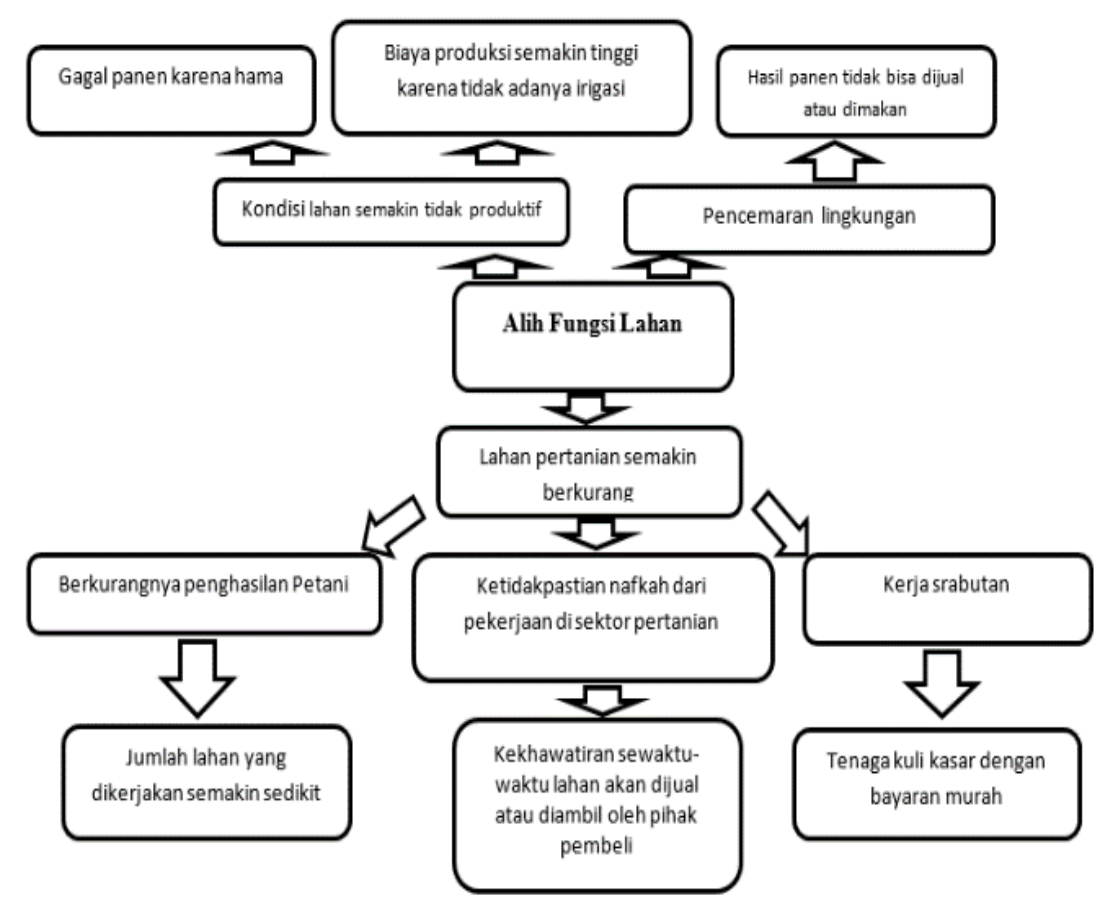

Diagram 1. Pemetaan Dampak Alih Fungsi Lahan Terhadap Orientasi Nafkah Rumah Tangga

Pemetaan hasil penelitian menggambarkan bahwa dampak dari alih fungsi lahan memiliki kaitan terhadap keberlangsungan pola nafkah petani di desa Namlea. Dampak yang dihasilkan sebagaimana arah panah yang ditunjukan dari dampak alih fungsi yaitu kondisi lahan yang semakin tidak produktif untuk pertanian dan pencemaran lahan pertanian akibat sulitnya mendapat air. Selain itu juga, dampak lain yang ditimbulkan yakni lahan pertanian menjadi semakin berkurang.

Alih fungsi lahan pertanian tidak hanya menyebabkan berkurangnya tenaga kerja bidang pertanian yang berpengaruh pada produksi komoditas, namun juga memberi dampak pada kehidupan sosial di masyarakat. Lahan bagi petani tidak hanya bernilai ekonomi namun juga sosial. Keterikatan antara lahan pertanian dan petanimenumbuhkan berbagai kearifan lokal yang mulai luntur seiring dengan berkurangnya lahan pertanian. Ketersediaan lahan pertanian yang semakin berkurang membuat aspek-aspek sosial dalam masyarakat ikut berubah seperti halnya modal sosial. Hal ini sangat disayangkan karena komponen-komponen modal sosial di dalam masyarakat seperti jaringan, norma dan kepercayaan merupakan bagian dari kehidupan sosial yang mendorong tindakan kolektif secara lebih efektif untuk mencapai tujuan-tujuan bersama. (Kusdiane et al., 2016). Bersamaan dengan terjadinya perubahan-perubahan dalam sistem pertanian dan pemanfaatan lahan di daerah pedesaan pada umumnya telah tumbuh pula aktifitas kerja luar pertanian, pertumbuhan aktivitas kerja ke luar pertanian ini ditandai oleh kejadian tipikal adanya pergeseran okupasi.

Memahami kondisi lahan semakin tidak produktif mengakibatkan dua hal pokok yang dijelaskan lewat panah ke atas, terpetakan menjadi gagal panen dan biaya produksi yang semakin tinggi akibat tidak adanya irigasi. Pada intinya, dampak alih fungsi lahan menghasilkan keterbatasan petani di desa Namlea untuk mengakses pekerjaan yang selama ini mereka dapatkan untuk memenuhi kebutuhan hidup dan harus mengerjakan pekerjaan lainnya tentu dengan bayaran yang murah, semua ini dilakukan semata-mata untuk memenuhi kebutuhan rumah tangganya. 


\section{SIMPULAN}

Keberlangsungan alih fungsi menyebabkan ketidakmampuan masyarakat tani di desa Namlea dalam hal pemenuhan kebutuhan hidup sehari-hari maka harus ada alternative yang dilakukan untuk tetap menjaga sumber-sumber penghidupan selain dari bertani. Pada waktu sebelumnya lahan pertanian di desa Namlea digunakaan sebagai sumber penghidupan para petani sebagai media untuk ditanami berbagai jenis tanaman produktif, seperti Ubi-ubian, sayur-sayuran serta tanaman umur Pendek. Namun di saat fungsi lahan mulai dialihkan dari lahan pertanian menjadi lahan untuk perumahan dan perkantoran maka situasi tersebut menjadi gambaran berubahnya fungsi lahan yang memiliki dampak dalam kehidupan sosial ekonomi masyarakat desa Namlea.

\section{UCAPAN TERIMAKASIH}

Ucapan terima kasih penulis sampaikan kepada pihak Direktorat Riset dan Pengabdian Masyarakat Kementerian Ristek Dikti yang telah memberikan kesempatan meneliti melalui hibah skema Penelitian Dosen Pemula Tahun 2020. Selain itu penulis juga berterima kasih kepada Ketua Lembaga Penelitian dan Pengabdian Masyarakat (LPPM), Kepala Pusat Studi Perencanaan Pembangunan Masyarakat (PSP2M) Universitas Iqra Buru atas dukungan yang diberikan selama penelitian dan penulisan artikel ini dilakukan hingga selesai.

\section{DAFTAR PUSTAKA}

R., Triputra, P., \& Napitupulu, F. (2020). Hashtag Construction As Product Of Symbolic Convergence: Berger And Luckmann's Approach. Journal Of Education, Society And Behavioural Science, 1-14. Https://Doi.Org/10.9734/Jesbs/2020/V33i1130267

Contzen, S., \& Crettaz, E. (2019). Being A Poor Farmer In A Wealthy Country: A Swiss Case Study. Sociologia Ruralis, 59(3), 393-418. Https://Doi.Org/10.1111/Soru.12230

Deng, X., Huang, J., Rozelle, S., Zhang, J., \& Li, Z. (2015). Impact Of Urbanization On Cultivated Land Changes In China. Land Use Policy. Https://Doi.Org/10.1016/J.Landusepol.2015.01.007

Et Al., M. C. B. U. (2021). Agricultural Land Conversion And The Influence Of The Food Supply Chain. Psychology And Education Journal, 58(1), 5518-5525. Https://Doi.Org/10.17762/Pae.V58i1.2168

Hardika, H. (2011). Transformasi Pola Matapencaharian Petani: Strategi Dan Perilaku Belajar Petani Di Kawasan Transisi Dalam Mengembangkan Kehidupan. Jurnal Pendidikan Dan Pembelajaran Universitas Negeri Malang, 18(1), 81-89.

Hidayat, Y., \& Et Al. (2017). Rumah Tangga Petani Padi ( Studi Kasus Kecamatan Kertajati Kabupaten Majalengka Jawa Barat ). Jurnal Pengkajian Dan Pengembangan Teknologi Pertanian, 20(2), 171-182.

Hudayana, B. (2020). The Impact Of Land Commodification On Small And Landless Farmer' S Access To Rent Land In The Sub-Urban Village* Dampak Komodifikasi Lahan Terhadap Akses Petani Kecil Dan Petani Tunakisma Pada Penyewaan Tanah Di Desa-Suburban Bambang Hudayana Department. Bhumi: $\begin{array}{llll}\text { Jurnal Agraria Dan 262-276. } & \text { 6(2), }\end{array}$ Http://Jurnalbhumi.Stpn.Ac.Id/Jb/Article/View/458/368

Kusdiane, S. D., Soetarto, E., \& Sunito, S. (2016). Alih Fungsi Lahan Dan Perubahan Masyarakat Di Kecamatan Cimanuk, Kabupaten Pandeglang. Journal Of Agribusiness Management.

Latang, L. (2017). Rasional Instrumental Dan Komersial Petani. Pembelajar: Jurnal Ilmu Pendidikan, Keguruan, Dan Pembelajaran, 1(2), 85. Https://Doi.Org/10.26858/Pembelajar.V1i2.4793

Mardiyaningsih, D. I., Dharmawan, A. H., \& Tonny, F. (2010). Dinamika Sistem Penghidupan Masyarakat Tani Tradisional Dan Modern Di Jawa Barat. Sodality: Jurnal Transdisiplin Sosiologi, Komunikasi, Dan Ekologi Manusia, 4(1), 115-145.

Pannell, D. J., Llewellyn, R. S., \& Corbeels, M. (2014). The Farm-Level Economics Of Conservation Agriculture For Resource-Poor Farmers. Agriculture, Ecosystems And Environment, 187, 52-64. Https://Doi.Org/10.1016/J.Agee.2013.10.014

Prasada, I. M. Y., \& Rosa, T. A. (2018). Dampak Alih Fungsi Lahan Sawah Terhadap Ketahanan Pangan Di Daerah Istimewa Yogyakarta. Jurnal Sosial Ekonomi Pertanian. Https://Doi.Org/10.20956/Jsep.V14i3.4805

Rahma, Satya At, A. (2021). Modernisasi Terhadap Perubahan Sosial Masyarakat Desa Namlea Kabupaten Buru. Nusantara: Jurnal Ilmu Pengetahuan Sosial, 8(1), 84-96. 
S. Ali, M. S., Yunus, A., \& Salman, D. (2018). Rasionalitas Petani Dalam Merespons Perubahan Kelembagaan Penguasaan Lahan Dan Sistem Panen Pada Usahatani Padi. Jurnal Sosial Ekonomi Pertanian, $14(1), 1$. Https://Doi.Org/10.20956/Jsep.V14i1.3643

Umanailo, R., Nawawi, M., Chairul Basrun Umanailo, M., Malik, S., \& Hentihu, I. (2019). Conversion Of Farmland Namlea Subdistrict. International Journal Of Scientific And Technology Research, 8(8), 18611864. Https://Doi.Org/10.6084/M9.Figshare.10721168

Vandercasteelen, J., Beyene, S. T., Minten, B., \& Swinnen, J. (2018). Big Cities, Small Towns, And Poor Farmers: Evidence From Ethiopia. World Development, 106, 393-406. Https://Doi.Org/10.1016/J.Worlddev.2018.03.006

Wijaya, H. (2018). Analisis Data Kualitatif Model Spradley (Etnografi). Sekolah Tinggi Theologia Jaffray, 3(1), $1-10$.

Zhang, W., Kato, E., Bianchi, F., Bhandary, P., Gort, G., \& Van Der Werf, W. (2018). Farmers' Perceptions Of Crop Pest Severity In Nigeria Are Associated With Landscape, Agronomic And Socio-Economic Factors. Agriculture, Ecosystems \& Environment, 259, 159-167. Https://Doi.Org/10.1016/J.Agee.2018.03.004 